\title{
The Wasatch Environmental Observatory: A mountain to urban research network in the semi-arid Western US
}

\author{
Jennifer Shah ${ }^{1}$, Ryan Bares ${ }^{1}$, Brenda Bowen ${ }^{1}$, Gabe Bowen ${ }^{1}$, David Eiriksson ${ }^{1}$, A. Gannett \\ Hallar $^{1}$, John Horel ${ }^{1}$, Sarah Hinners ${ }^{1}$, Logan Jamison ${ }^{1}$, John Lin ${ }^{1}$, Diane Pataki ${ }^{1}, \mathrm{~S}$. \\ McKenzie Skiles ${ }^{1}$, Rose Smith ${ }^{1}$, Margaret Wolf ${ }^{1}$, and Paul Brooks ${ }^{1,1}$ \\ ${ }^{1}$ University of Utah
}

October 5, 2020

\begin{abstract}
The Jordan River Basin, and its seven sub-catchments of the Central Wasatch Mountains immediately east of Salt Lake City, $\mathrm{UT}$, are home to an array of research infrastructrure that collectively form the Wasatch Environmental Observatory (WEO). Each sub-catchment is comprised of a wildland to urban land use gradient that spans an elevation range of over $2000 \mathrm{~m}$ in a linear distance of $\sim 25 \mathrm{~km}$. Geology varies across the sub-catchments, ranging from granitic, intrusive to mixed sedimentary rocks in uplands that drain to the alluvial or colluvial sediments of the former Lake Bonneville. Vegetation varies by elevation, aspect, distance to stream channels, and land use. The sharp elevation gradient results in a range of precipitation from 700 to $1200 \mathrm{~mm} / \mathrm{yr}$ (roughly $2 / 3$ as snow) and mean annual temperature from $3.5^{\circ}$ to $6.8^{\circ} \mathrm{C}$. Spring snowmelt dominates annual discharge. Although climate is relatively similar across the catchments, annual water yield varies spatially by more than a factor of 3, ranging from 0.18 to 0.63 . With historical strengths in ecohydrology, water supply, and social-ecological research, current infrastructure supports both basic and applied research in meteorology, climate, atmospheric chemistry, hydrology, ecology, biogeochemistry, resource management, sustainable systems, and urban redesign. Climate and discharge data span over a century for the seven sub-catchments of the larger basin. These data sets, combined with multiple decades of hydrochemistry, isotopes, ecological data sets, social survey data sets, and high-resolution LiDAR topography and vegetation structure, provide a baseline for long-term data collected by NEON, public agencies, and individual research projects. The combination of long-term data with active state of the art observing facilities allows WEO to serve as a unique natural laboratory for addressing research questions facing rapidly growing, seasonally snow-covered, semi-arid regions worldwide and an excellent facility for providing student education and research training.
\end{abstract}

\section{Site Description}

The Wasatch Environmental Observatory (WEO) integrates existing fixed and mobile field-based research infrastructure in central Utah, USA $\left(40^{\circ} 34^{\prime} \mathrm{N}, 111^{\circ} 53^{\prime} \mathrm{W}\right)$. This distributed observational network supports research and training in multiple disciplines. The WEO is managed by the University of Utah and supported by two full-time, highly skilled technicians. The unique geography of the region allows the WEO to span gradients from relatively unimpacted mountain environments to century-old urban landscapes, all of which are facing major challenges related to global changes and a growing human population. The integration of a city-center within the study area provides benefits to the WEO, such as the ability to affix scientific instrumentation to mass transit; work with community partners to construct experimental, yet operational green infrastructure facilities; and augment WEO infrastructure with instrumentation managed by state and federal agencies.

WEO is named for the Central Wasatch Mountains, east of Salt Lake City, Utah, USA (Fig. 1A). The Wasatch Range represents the western edge of the Rocky Mountain physiographic province with the Jordan 
(Salt Lake) River Basin marking the eastern boundary of the Basin and Range province. The Wasatch fault bounds the range to the west and is responsible for over $2200 \mathrm{~m}$ of relief between the mountain peaks $(>3500 \mathrm{~m})$ and the valley floor $(\sim 1300 \mathrm{~m})$. The mountain block is lithologically and structurally complex with rocks ranging from Precambrian quartzites and shales to Tertiary igneous intrusions (Bryant 1990). The Jordan River Basin is bordered by mountains in all directions but the northwest, resulting in a geography that promotes atmospheric inversions in summer and winter months (Lin et al., 2018). Roughly $44 \%$ of the $2,085 \mathrm{~km}^{2}$ Jordan River catchment area is urban, with a human population of 1.1 million living in Salt Lake County that is expected to reach 1.7 million by 2065 (Perlich et al., 2017). The mainstem Jordan River receives inputs from Utah Lake at the southern extent of the basin and flows north to the Great Salt Lake. Seven major tributaries drain the Central Wasatch Mountains and discharge to the river after passing through several municipalities (Fig. 1B). Each sub-catchment thus represents varying degrees of a wildland to urban land use gradient. For example, Red Butte Canyon includes a U.S. Forest Service Research Natural Area (RNA) in its headwaters (Ehleringer et al., 1992), while high altitude areas of Big and Little Cottonwood canyons are home to multiple ski resorts.

The region has a cold, semi-arid climate with strong lapse rates in mean annual temperature (MAT) and precipitation (MAP) at the sub-catchment scale. MAT within the Central Wasatch $(1300-3500 \mathrm{~m})$ ranges from $3.5-6.8^{\circ} \mathrm{C}$, while MAP varies between $700-1300 \mathrm{~mm}$. In Red Butte Creek $(1300-2510 \mathrm{~m})$, MAT is $6.8^{\circ} \mathrm{C}$ and MAP is $850 \mathrm{~mm}$ (Gelderloos, 2018).

In Little Cottonwood Creek (1600 - $3500 \mathrm{~m}$ ), which includes the intensively studied alpine Albion Basin, MAT is $3.5^{\circ} \mathrm{C}$, while MAP is $1300 \mathrm{~mm}$. Most precipitation falls as winter snow with spring melt (April July) providing both surface water runoff and regional groundwater recharge (Hely et al., 1971; Manning \& Solomon, 2004; Bardsley, et al. 2013; Gabor et al., 2017). Numerous water diversions from tributaries and the mainstem river combined with inputs of effluent from several water reclamation facilities and canal return flows add hydrologic complexity to the system (Follstad Shah et al., 2019). The fourth-order Jordan River is on the state of Utah's 303(d) list of impaired water bodies (U.S. Code 1313(d)(1)(A) in many of its segments due to highly regulated river flows and excessive loading of organic matter and nutrients (Follstad Shah et al., 2019).

WEO instrumentation combined with long-term climate and stream discharge data provide evidence of rapid climatic and hydrologic change in the Jordan River Basin. Mean annual air temperature in each subcatchment has increased by approximately $1.5^{\circ} \mathrm{C}$ since 1980 (Fig. 2) (Wolf, 2020; Jamison, 2020). Downscaled climate models suggest that more precipitation will fall as rain rather than snow in the future and the snow line will shift upslope by $250 \mathrm{~m}$ (Scalzitti et al., 2016). These changes will create flashier hydrographs within Jordan Basin tributaries, historically characterized as snowmelt dominated. Reduced flows to the Great Salt Lake, induced by shifting climate and water extraction, have already exposed more lake sediment, lending to dust storms that substantially accelerate snow melt (Skiles et al., 2018) and exacerbate air pollution in a region prone to high concentrations of fine particulate matter and the formation of photochemical smog (Lin et al., 2018; Fig. 3).

In short, hydrologic process research opportunities abound in the region given its unique geography, rapidly growing human population that puts pressure on water resources, hydrologic change resulting from the climate crisis, and clear linkages between the hydrologic cycle and air quality. We now summarize some of the major avenues of research supported by the WEO and provide greater detail about the infrastructure supporting these efforts.

\section{Research Themes \& Major Findings}

\section{Hydrology}

Over a century of streamflow monitoring from the seven main sub-catchments draining the Central Wasatch indicate that mean annual water yield ranges from $18 \%$ to $63 \%$ with higher water yield from colder, wetter, steeper catchments (Gelderloos, 2018; Jamison, 2020; Wolf, 2020). Hydrochemical observations from U.S. Geology Survey (USGS) baseline network indicate that most of this surface water discharge has had 
extensive interaction with the subsurface (Godsey et al., 2009). The evidence that snowmelt drives both surface water discharge and groundwater recharge has led to extensive focus on surface water-groundwater interactions using a suite of tracers (Manning \& Solomon, 2004; Manning et al., 2005). These studies demonstrate that mountain block recharge is large, driven by snowmelt, and that regional groundwaters are dominated by modern water with apparent ${ }^{3} \mathrm{H} /{ }^{3} \mathrm{He}$ ages of 5 to 50 years. Younger waters are found close to the mountain front. Recent findings that snowmelt is decreasing due to long-term warming (Jamison, 2020) while proceeding more rapidly due to episodic dust deposition (Skiles et al., 2018) suggest that historical patterns in recharge and streamflow are unlikely to predict future water supply. These results have important implications for drinking water supply given that winter montane precipitation is an important source for tap water in the Salt Lake Valley (Jameel et al., 2016; 2018).

\section{Ecohydrology}

Complementing the work on snowmelt, recharge, and streamflow, WEO has long been a location where researchers use novel methods to understand where plants obtain water, their susceptibility to climate and drought stress and their distribution across the landscape. For example, early work showed that riparian trees do not use stream water (Dawson \& Ehleringer, 1991; Oerter et al., 2019) leading to decades of work around the globe on understanding plant water sources. More recently, experimental plot-based studies, observations in natural forest stands, and landscape modeling are demonstrating how plant physiology interacts with local to regional climate to control dormancy, growth, carbon allocation, and drought stress (Chan \& Bowling, 2017; Zenes et al., 2020). Analysis of high-resolution LiDAR data has illustrated how human land use decisions interact with local hydroclimate to influence both demography and productivity of riparian vegetation across the wildland to urban land use gradient (Grijseels et al., in review).

\section{Water Supply $\&$ Water Quality}

WEO researchers have leveraged existing gradients in water isotope values $\left(\mathrm{d}^{18} \mathrm{O}\right.$ and $\mathrm{d}^{2} \mathrm{H}$ in surface water, groundwater, precipitation, drinking water, and effluent) across the Jordan River Basin and monitoring of discharge and hydrochemistry to better understand complexities in the supply of surface water and drinking water (Jameel et al., 2016; 2018; Follstad Shah et al., 2019), as well as relationships between water supply and water quality (Hall et al., 2016; Gabor et al., 2017). These studies demonstrate how water isotopes can be a tool for public utilities to identify where to monitor for unintended reactions within pipes receiving water from multiple sources, isolate areas of water-related public health emergencies, and better manage impaired waterways. Studies in Jordan River tributaries also indicate that snowmelt-dominated groundwater is a significant contributor to discharge along the montane to urban gradient and show that shallow, polluted groundwater in highly urban areas as the source of elevated stream nutrient loads (Hall et al., 2016; Gabor et al., 2017). These results challenge the existing paradigm linking stormwater inputs to poor water quality in urban streams.

Two facilities exist at the University of Utah that provide opportunities for assessing the efficacy of green infrastructure to manage stormwater inputs and retain nutrients. The Green Infrastructure Research Facility (GIRF) is an experimental set of bioswales where hydrologic inputs, water chemistry, and vegetation can be fully manipulated. Work at this site has demonstrated that bioswales with irrigated wetland vegetation and un-irrigated xeric adapted upland vegetation retained similar amounts of phosphorus, while wetland swales retained more nitrogen (Houdeshel et al., 2015). The Landscape Lab (http://cepd.cap.utah.edu/landscape$l a b /)$ consists of eight bioswales receiving runoff from adjacent structures and streets. Bioswales are planted with either mesic, ornamental vegetation or drought-adapted vegetation, with equal replication of each treatment. The site was established through a designed experiment process (Felson and Pickett, 2005), as both a demonstration project for stormwater management in semi-arid regions, and a research site to address how ecohydrology and ecology affect green infrastructure function.

\section{Climate 83 Atmospheric Science}

Decades of investment in meteorological and trace gas monitoring by the University of Utah has provided the foundation for diverse environmental research, served civic needs (Horel et al., 2002) and resulted in 
one of the longest continuous records of urban carbon dioxide $\left(\mathrm{CO}_{2}\right)$ concentrations in the nation (Lin et al., 2018; Bares et al., 2019). This investment has better elucidated the factors contributing to poor air quality in the Salt Lake Valley, including population growth (Mitchell et al., 2018) and secondary formation of $\mathrm{PM}_{2.5}$ through reactions of aerosols containing ammonium with a variety of other pollutants emitted from local sources (Moravek et al., 2019; Womak et al., 2019). Results from recent studies also have provided new modeling and empirical tools for monitoring air quality and transport processes of air pollutants (e.g., Mallia et al., 2017; Bares et al., 2018).

\section{Instrumentation \& Measurements}

The WEO is comprised of several instrumentation networks, described in detail below, that can be enhanced by measurements using relocatable, high-precision hydrologic and atmospheric observation equipment (Fig. 4). Example deployable equipment includes scintillometers, ground penetrating radar, neutron and time domain reflectometry, cosmic ray probes for biomass and soil moisture, lysimeters, collars for sampling gas flux from soils, hydrologic sondes, automated water samplers, portable trace gas infrared analyzers, and portable aerosol spectrophotometers. The WEO also includes databases with high resolution LiDAR data and longterm records of environmental monitoring (e.g., isotopes, weather, atmospheric trace gases and chemistry, water quality). WEO resources are augmented by hydrological, meteorological, and ecological infrastructure managed by the USGS, US Department of Agriculture National Resource Conservation Service (NRCS), National Ecological Observatory Network (NEON), Inc., Utah Department of Transportation (UDOT), and Salt Lake County.

\section{Instrumentation Networks}

Thirty stream gages exist within the Jordan Basin, amongst those operated by the WEO, USGS, NEON Inc., and Salt Lake County. Real-time discharge and stage height data from each gage is available online. Some also report water temperature. Several stormwater discharge points within Red Butte Creek also have been instrumented with sensors continuously monitoring discharge and water temperature. Episodic sampling has enhanced these measurements with analysis of metals and water isotopes in stormwater.

WEO's Gradient Along Mountain to Urban Transect (GAMUT) network, installed as part of the 5-year (2012-2018) innovative Urban Transitions and Arid-region Hydrosustainability (iUTAH) program (https://iutahepscor.org/; Jones et al., 2017) includes six coupled terrestrial climate and stream ecohydrology stations located along the wildland to urban land use gradient from the headwaters of Red Butte Canyon to the Jordan River on the Salt Lake Valley floor. Since installation, meteorological stations have continuously recorded incoming and outgoing radiation, vapor pressure, barometric pressure, air temperature, wind speed and direction, ground-level ozone $\left(\mathrm{O}_{3}\right)$, precipitation, snow depth, photosynthetically active radiation (PAR), and soil moisture. Aquatic stations have since continuously recorded stream discharge, water temperature, $\mathrm{pH}$, specific conductance, dissolved oxygen, turbidity, colored dissolved organic matter, phycocyanin, and chlorophyll. Data from these stations have been augmented by biweekly sampling for water chemistry (e.g., nutrient and dissolved organic carbon concentrations) and Escherichia coli abundance. Periodic synoptic sampling campaigns have complemented these measurements with analysis of isotopes from water, plant tissues, and stream macroinvertebrate communities. Social science surveys conducted as part of the iUTAH program have provided rich information for understanding human perceptions of and access to regional water resources.

One of the permanent observation sites operated by NEON Inc., is located in the Red Butte Canyon RNA. Instrumentation at this site includes sensors that monitor stream discharge and temperature, surface water quality, depth to groundwater, precipitation, eddy covariance, soil moisture, and phenology.

Green infrastructure facilities at the University of Utah have been equipped with automated flow sensors to monitor hydrologic fluxes in and out of bioswales, as well as soil moisture sensors.

Several long-term snowpack study plots exist in the Central Wasatch and are managed by the NRCS and UDOT. These study sites provide information about snowpack depth, density, and snow water equivalent, 
as well as meteorological data in some cases. At the Atwater Study Plot (ASP; 40.591206 N, 111.637685 W), WEO researchers have paired measurement and aerosol deposition to understand the effect of dust on rates of snowmelt (Skiles et al., 2018). ASP has recently been instrumented to measure radiation fluxes, providing the first full snow energy balance estimates in the Central Wasatch Range. A radiometer with aerosol optical depth measurement capability is located atop a building on the campus of the University of Utah. Additional urban and montane sites will be equipped with dust emission and deposition sensors in the near future.

The Utah Urban $\mathrm{CO}_{2}$ Network (UUCON) includes eight trace gas stations throughout the Salt Lake Valley that span a large elevational gradient extending from Hidden Peak in Albion Basin to the valley floor (Lin et al., 2018; Bares et al., 2019). All of these stations monitor $\mathrm{CO}_{2}$ concentrations, but some stations also record other gases $\left(\mathrm{CO}, \mathrm{CH}_{4}, \mathrm{NO}_{\mathrm{x}}, \mathrm{O}_{3}\right)$, isotopes, and fine particulate matter $\left(\mathrm{PM}_{2.5}\right)$. In addition, sensors affixed to Utah Transit Authority's light rail system measure emissions of $\mathrm{CO}_{2}, \mathrm{CH}_{4}, \mathrm{O}_{3}$, and $\mathrm{PM}_{2.5}$ in the urban core (TRAX; Lin et al. 2018; Mitchell et al., 2018; Mendoza et al., 2019) and a mobile lab is driven around the metropolitan area on a regular basis measuring concentrations of $\mathrm{CO}, \mathrm{CO}_{2}, \mathrm{CH}_{4}, \mathrm{NO}_{\mathrm{x}}, \mathrm{O}_{3}$ and $\mathrm{PM}_{2.5}$. Together, UUCON and these mobile monitoring platforms comprise the Salt Lake Valley Greenhouse Gas Monitoring System (Lin et al., 2018). Trace gas monitoring is augmented with meteorological data housed by the MesoWest network (Horel et al., 2002). These meteorological data have been collected since 1997 from hundreds of locations throughout the WEO region.

\section{Data Availability}

Stream discharge data collected by non-WEO entities are available at USGS ( $h t t-$ ps://waterdata.usgs.gov/nwis) and Salt Lake County (https://rain-flow.slco.org/) websites. GAMUT network data can be retrieved from Hydroshare (https://www.hydroshare.org/), currently managed by the Consortium of Universities for the Advancement of Hydrologic Science, Inc. (CUAHSI). NEON Inc. manages a data portal from which data may be downloaded (https://data.neonscience.org/dataproducts/explore). Snow study plot data can be found at the NRCS snow telemetry (SNOTEL) website (https://www.wcc.nrcs.usda.gov/snow/). UUCON data can be visualized and downloaded through the Utah Atmospheric Trace Gas and Air Quality Laboratory (https://air.utah.edu/). Meteorological data and Atwater Study Plot data can be obtained through MesoWest (http://meso2.chpc.utah.edu/aq/ and https://mesowest.utah.edu/cgi-bin/droman/meso_base_dyn.cgi?stn=ATH20). High resolution LiDAR data covering the seven catchments are available athttps://gis.utah.gov/data/elevationterrain-data/2-meter-lidar/. Water isotope data can be found through WaterIstopes.org (https://wateriso.utah.edu/waterisotopes/).

\section{Acknowledgments}

WEO infrastructure has been supported through grants from the U.S. National Science Foundation (OIA1208732, DEB-2006308, DBI-1759730, EAR-2012091, IOS 1450650, CZO 1331408) and financial contributions from Salt Lake County Public Utilities and the University of Utah.

\section{References}

Bardsley, T., Wood, A., Hobbins, M., Kirkham, T., Briefer, L., Niermeyer, J., \& Burian, S. (2013). Planning for an Uncertain Future: Climate Change Sensitivity Assessment toward Adaptation Planning for Public Water Supply. Earth Interactions,17, (23), 1-26. https://doi: 10.1175/2012EI000501.1.

Bares, R., Lin, J.C., Hoch, S.W., Baasandorj, M., Mendoza, D.L., Fasoli, B., .. \& Stephens, B.B. (2018). The wintertime covariation of CO2 and criteria pollutants in an urban valley of the western United States. Journal of Geophysical Research: Atmospheres , 123, 2684-2703. https:// doi.org/10.1002/2017JD027917

Bares, R., Mitchell, L., Fasoli, B., Bowling, D.R., Catharine, D., Garcia, M., .. \& Lin, J.C. (2019). The Utah carbon dioxide (UUCON) and Uintah Basin greenhouse gas networks: instrumentation, data, and measurement uncertainty. Earth System Science Data , 11, 1291-1308.

Bryant, B. (1990). Geologic map of the Salt Lake City 30' x 60' quadrangle, north-central Utah, and Uinta 
County, Wyoming, U.S. Geological Survey Miscellaneous Investigations Series Map, I-1944.

Chan, A.M. \& Bowling, D.R. (2017). Assessing the thermal dissipation sap flux density method for monitoring cold season water transport in seasonally snow-covered forests. Tree Physiology , 27(7), 984-995. https://doi.org/10.1093/treephys/tpx049.

Dawson, T. \& Ehleringer, J.(1991). Streamside Trees that do not use Stream Water. Letters to Nature, 350, 335-337.

Ehleringer, J. R., Anrow, L. A., Anrow, T., McNulty, I. \& Negus, N. (1992). Red Butte Canyon Research Natural Area- History, Flora, Geology, Climate and Ecology, The Great Basin Naturalist, 52(2), 95-121.

Felson, A.J. \& Pickett, S.T.A. (2005). Designed experiments: New approaches to studying urban ecosystems, Frontiers in Ecology and the Environment , 3(10), 549-556.

Follstad Shah, J.J., Jameel, Y., Smith, R.M., Gabor, R.S., Brooks, P.D. \& Weintraub, S.R. (2019). Spatiotemporal variability in water sources controls chemical and physical properties of a semi-arid urban river system, Journal of the American Water Resources Association , 55(3), 591-607.

Gabor, R.S., Hall, S.J., Eiriksson, D.P., Jameel, Y., Millington, M., Stout, T., .. \& Brooks, P.D. (2017). Persistent urban influence on surface water quality via impacted groundwater, Environmental Science and Technology , 51(17), 9477-9487. https://doi:10.1021/acs.est.7b00271.

Gelderloos, A. (2018). Quantifying the interaction between climate and landscape on water resources, MS Thesis, University of Utah, Salt Lake City, Utah, USA.

Godsey, S.E., Kirchner, J.W., \& Clow, D.W. (2009). Concentration-discharge relationships reflect chemostatic characteristics of US catchments. Hydrological Processes , 23(13), 1844-1864. https://doi.org/10.1002/hyp.7315.

Grijseels, N.H., M. Buchert, P.D. Brooks, \& D.E. Pataki. (In Revision). Using LiDAR to assess transitions in riparian vegetation structure along a rural-to-urban land use gradient in western North America, Ecohydrology

Hall, S.J., Weintraub, S.R., Eiriksson, D., Brooks, P.D., Baker, M.A., Bowen, G.J., \& Bowling D.R. (2016). Stream nitrogen inputs reflect groundwater across a snowmelt-dominated montane to urban watershed.Environmental Science and Technology , 50(3), 1137-1146.

Hely, A.G., Mower, R.W., Harr, C.A., \& Arnow, T. (1971). Water Resources of Salt Lake County, Utah (Other Government Series No. 31), Utah Department of Natural Resources, Division of Water Rights, Salt Lake City, Utah, USA, 240 pp. Retrieved from http://waterrights.utah.gov/docSys/v920/w920/w920008t.pdf.

Horel, J., Splitt, M., Dunn, L., Pechmann, J., White, B., Ciliberti, C., . . \& Burks, J. (2002). MesoWest: Cooperative Mesonets in the Western United States. Bulletin of the American Meteorological Society, 83, 211-226. http://dx.doi.org/10.1175/1520-0477(2002)083<0211:MCMITW > 2.3.CO;2

Houdeshel, C.D., Hultine, K.R., Johnson, N.C. \& Pomeroy, C.A. (2015). Evaluation of three vegetation treatments in bioretention gardens in a semi-arid climate, Landscape and Urban Planning , 135, 62-72.

Jameel, Y., Brewer, S., Good, S.P., Tipple, B.J., Ehleringer, J.R., \& Bowen, G.J. (2016). Tap water isotope ratios reflect urban water system structure and dynamics across a semiarid metropolitan area. Water Resources Research , 52(8), 5891-5910.

Jameel, Y., Brewer, S., Fiorella, R.P., Tipple, B.J., Terry, S., \& Bowen G.J. (2018). Isotopic reconnaissance of urban water supply system dynamics. Hydrology and Earth System Sciences , 22, 6109-6125.

Jamison, L.R. (2020). Seasonal snowmelt and multi-year groundwater dynamics control interannual variability in water yield, MS Thesis, University of Utah, Salt Lake City, Utah, USA. 
Jones, A.S., Aanderud, Z.T., Horsburgh, J.S., Eiriksson, D.P., Dastrup, D., Cox, C., . . \& Baker, M.A. (2017). Designing and implementing a network for sensing water quality and hydrology across mountain to urban transitions. Journal of the Water Resources Association, 53(5), 1095-1120. https://doi.org/10.1111/17521688.12557 .

Lin, J.C., Mitchell, L., Crosman, K., Mendoza, D.L., Buchert, M., Bares, R., .. \& E Ehleringer, J.R. (2018). $\mathrm{CO}_{2}$ and carbon emissions from cities: Linkages to air quality, socioeconomic activity, and stakeholders in the Salt Lake City urban area. American Meteorological Society, 99(11), 2325-2339.

Mallia, D.V., Kochanski, A., Wu, D. Pennell, C., Oswald, W. \& Lin, J.C. (2017). Wind-blown dust modeling using a backward-lagrangian particle dispersion model. Journal of Applied Meteorology and Climatology, 56(10), 2845-2867. https://doi.org/10.1175/JAMC-D-16-0351.1.

Manning, A.H., \& Solomon, D.K., (2004). Constraining mountain-block recharge to the eastern Salt Lake Valley, Utah with dissolved noble gas and tritium data. Groundwater recharge in a desert environment: the southwestern United States, pp.139-158.

Manning, A.H., Solomon, D.K., \& Thiros, S.A. (2005). 3H/3He age data in assessing the susceptibility of wells to contamination. Groundwater , 43(3), 353-367.

Mendoza, D.L., Crosman, E.T., Mitchell, L.E., Jacques, A.A., Fassoli, B., Park, A.M., Lin, J.C., \& Hotel, J.D. (2019). The TRAX light-rail train air quality observation project. Urban Science , 3(4), 108. https://doi.org/10.3390/urbansci3040108.

Mitchell, L.E., Lin, J.C., Bowling, D.R., Pataki, D.E., Strong, C., Schauer, A.J., .. \& Ehleringer, J.R. (2018). Long-term urban carbon dioxide observations reveal spatial and temporal dynamics related to urban characteristics of and growth. Proceedings of the National Academy of Science, 115(12), 2912-2917.

Moravek, A., Murphy, J.G., Hrdina, A., Lin, J.C., Pennell, C., Franchin, A., .. \& Brown, S.S. (2019). Wintertime spatial distribution of ammonia and its emission in the Great Salt Lake region.Atmospheric Chemistry and Physics , 19, 15691-15709.

Oerter, E.J., Siebert, G., Bowling, D.R., \& Bowen, G. (2019). Soil water vapour isotopes identify missing water sources for streamside trees. Ecohydrology , 12(4), e2083. https://doi.org/10.1002/eco.2083.

Perlich, P.S., Hollingshaus, M., Harris, E.R., Tennert, J., \& Hogue, M.T. (2017). Research brief: Utah's long term and economic projections summary. Kem C. Gardner Policy Institute, University of Utah, Salt Lake City, Utah, USA. 32 pp. Retrieved from https://gardner.utah.edu/wp-content/uploads/Projections-BriefFinal.pdf.

Scalzitti, J., Strong, C., \& Kochanski, A. (2016). Climate change impact on the roles of temperature and precipitation in western U.S. snowpack variability, Geophysical Research Letters , 43(10), 5361-5369. https://doi.org/10.1002/2016GL068798

Skiles, S.M., Flanner, M., Cook, J.M., Dumont M., \& Painter, T.H. (2019). Radiative forcing by lightabsorbing particles in snow.Nature Climate Change, 8, 964-971.

Wolf, M.A. (2020). Multi-annual climate controls of groundwater storage contributions to streamflow in Wasatch Front and Weber River headwater catchments, MS Thesis, University of Utah, Salt Lake City, Utah, USA.

Womack, C.C., McDuffie, E.E., Edwards, P.M., Bares, R., de Gouw, J.A., Docherty, K.S., .. \& Brown, S.S. (2019). An odd oxygen framework for wintertime ammonium nitrate aerosol pollution in urban areas: $\mathrm{NO}_{\mathrm{x}}$ and VOC control as mitigation strategies. Geophysical Research Letters , 46(9), 4971-4979.

Zenes, N., Kerr, K., Trugman, A.T., \& Anderegg, W.R.L. (2020). Competition and drought alter optimal stomatal strategy in tree seedlings. Frontiers in Plant Science, 11, 478. https://doi.org/10.3389/fpls.2020.00478

Figure Legends 
Figure 1. The Wasatch Environmental Observatory (WEO) network study area encompasses the Central Wasatch Mountains and the Salt Lake Valley (A), within which exists the Jordan River Basin and seven sub-catchments (B). Acronyms in (B) represent the names of each sub-catchment: City Creek (CC), Red Butte Creek (RBC), Emigration Creek (EC), Parleys Creek (PC), Mill Creek (MC), Big Cottonwood Creek (BCC), and Little Cottonwood Creek (LCC).

Figure 2. Mean annual temperature and streamflow for the seven tributaries draining the Central Wasatch Mountains from the water years (October-September) of 1900 to the present.

Figure 3. Image of an atmospheric inversion trapping air pollution within the Salt Lake Valley. Photo credit: Jeffrey D. Allred, Associated Press.

Figure 4. Panel showing instrumentation positioned in various locations throughout the WEO, including the headwaters of Red Butte Creek (A,B), the Green Infrastructure Research Facility (GIRF) on the campus of the University of Utah (C), the mobile light rail system (D), and Albion Basin (E).

Figure 1.

\section{Hosted file}

image1.emf available at https://authorea.com/users/364480/articles/484890-the-wasatchenvironmental-observatory-a-mountain-to-urban-research-network-in-the-semi-arid-westernus

\section{Figure 2.}

\section{Hosted file}

image2.emf available at https://authorea.com/users/364480/articles/484890-the-wasatchenvironmental-observatory-a-mountain-to-urban-research-network-in-the-semi-arid-westernus

\section{Figure 3.}

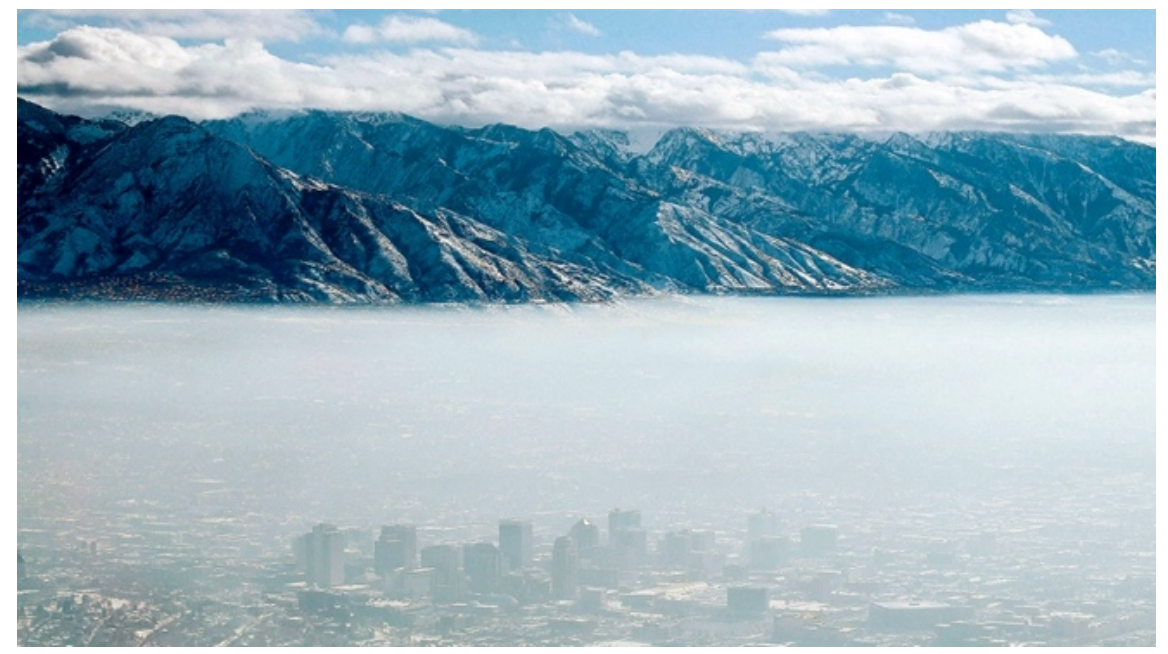

\section{Figure 4 .}

\section{Hosted file}

image4.emf available at https://authorea.com/users/364480/articles/484890-the-wasatchenvironmental-observatory-a-mountain-to-urban-research-network-in-the-semi-arid-westernus 